\title{
MARRIAGE BY PROXY AND THE CONFLICT OF LAWS
}

\section{I}

THE question whether a marriage may be celebrated by proxy 1 has been of very little practical importance in modern times. So far as England and America are concerned no mention is made of marriage by proxy in the books of the nineteenth and twentieth centuries. The only discussion of the subject in the English language that has come to the notice of the writer is found in Swinburne's "Law of Espousals" which was first published in the latter part of the seventeenth century. The continental writers also, who are more inclined to discuss problems of a purely theoretical nature have paid little attention to the subject in recent times. ${ }^{2}$ The legislation of the present war, however, has given to the subject renewed importance, for in three of the continental countries Belgium, France, and Italy - marriage by proxy has been expressly sanctioned by law. The presence of so many American soldiers abroad naturally raises the question whether they may contract a marriage by proxy either by virtue of the American law or by virtue of the law of the country in which they may happen to be for the time being. Before an answer can be given to these questions the subject of marriage by proxy must be considered both from the standpoint of the internal law of the principal countries concerned and from the viewpoint of the American rules relating to the conflict of laws.

That marriage by proxy was allowed in the late Roman law and in the Canon Law is an established fact. Pomponius says: ${ }^{3}$

"Mulierem absenti per litteras eius vel per nuntium posse mubere placet, si in domum eius deduceretur: eam vero quae abesset ex litteris vel mutio

1 The first edition appeared in $I 686$, the second in $I 7 \mathrm{rr}$.

$22 \mathrm{v}$. SCHERER, HANDBUCH DES KIRCHENRECHTS (page X92) gives the following bibliography: ArIens, De NUPTIIS, QUAE PER ProcuRatoreM Contrahuntur, Traj. I84I; Kutschker, E.R. 4, 32I-46; LUDewtg, De Matrdaronto PrIncIPIs per Procuratores, I736; Müller, De Matrinonio Absentiun, I740; Sanchez, De Sancto Matrimonil Sacramento Disputationuar Tomi Tres, LII, Disp. in; Schöpfer, De MatriMONIO PER SUBSTITUTUM CONTRACTO, I7O9.

8 DIGEST, XXIII, 2, 5 . 
suo duci a marito non posse: deductione enim opus esse in marití, non in uxoris domum, quasi in domicilium matrimonii."

According to this passage a man who was away from home might marry a woman by letter or messenger, but marriage could not be contracted in this manner by a woman who was absent from the man's place of residence. The reason for this difference between the man and the woman resulted from the requirement of the Roman law that the wife be led to the husband's home (deductio in domum mariti). Marriage was considered in the late Roman law as based solely upon the agreement of the parties to take each other from that moment as husband and wife. ${ }^{4}$ This consent might be expressed, with the reservation above made, by letter or by agent (per nuntium vel epistulam) as in all ordinary consensual contracts.

The Canon Law accepted as its fundamental doctrine the principle that consensus facit nuptias. Gratian ${ }^{5}$ insisted that there was no marriage unless the agreement of the parties to take each other as husband and wife was followed by cohabitation, but this requirement did not prevail. Peter Lombard, professor at the University of Paris, and later ordained bishop, suggested a distinction in this regard between sponsalia de praesenti and sponsalia per verba de futuro, requiring cohabitation only for the validity of the latter. Through the influence of Alexander III the church accepted this distinction toward the end of the twelfth and at the beginning of the thirteenth centuries. ${ }^{6}$ Parties declaring in words of the present tense that they take each other from that moment as husband and wife were regarded as legally married. ${ }^{7}$ The only difference between a marriage that was consummated through cohabitation and one that was not so consummated was that the latter might be dissolved by entering religion and was subject to the papal power of dispensation. ${ }^{8}$

From the earliest times the church had insisted that the parties should exchange matrimonial consents in face of the church and should get their union blessed by the church, but a failure to observe

4 NUPTIAS ENIM NON CONCUBITUS, SED CONSENSUS FACIT, D. 35, I, I5; D. 50, I7, 30.

5 I Esmen, Le Mariage en Drott Canonique, iog; i Howard, History or Matrimoniar Institutions, 336.

- I EsMen, supra, r27.

7 i Howard, supra, 337; 3 Boenaner, Jus Ecclestasticum Protestantum, 3 ed., Bk. 4, Tit. I, No. I3.

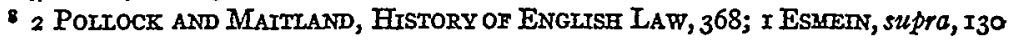


these requirements did not render the marriage void. ${ }^{9}$ At the Lateran Council of I2 5 Pope Innocent III extended for the whole Western Christendom the requirement of the publication of banns. A marriage with banns had certain legal advantages over a marriage without banns; but the formless, unblessed marriage was nevertheless valid. ${ }^{10}$

Innocent III accepted the Roman view that the marriage contract, being based upon the present consent of the parties, might be entered into by messenger. ${ }^{\text {.1 }}$ Some of the canonists, following the example of the Roman law, maintained that only the man should be permitted to marry in this manner, ${ }^{12}$ but it was felt that the same rule should apply to both parties. ${ }^{13}$ Others contended that a marriage contract was different from an ordinary consensual contract, the expression of consent being of such far reaching consequences that it should be expressed in person instead of by proxy. This objection was met by the technical argument that a procurator represented the person of his principal and that the latter could pronounce the words through the procurator's mouth, as it were. ${ }^{14}$ This view triumphed and found expression in the following decretal of Boniface VIII:15

"Procurator non aliter censetur idoneus ad matrimonium contrahendum, quam si ad hoc mandatum habuerit speciale. Et quamvis alias is, qui constituitur ad negotia procurator, alium dare possit: in hoc tamen casu, propter magnum quod ex facto tam arduo posset periculum imminere, non poterit deputare alium, nisi hoc eidem specialiter sit commissum. Sane si procurator, antequam contraxerit, a domino fuerit revocatus, contractum postmodum matrimonium ab eodem, licet tam ipse quam ea, cum qua contraxerit, revocationem huiusmodi penitus ignorarent, mullius -momenti exsistit, quum illius consensus defecerit, sine quo firmitatem habere nequevit."

9 I EsMren, supra, 96 .

102 Pollock and Mairland, supra, 369; Brouwer, De Jure Connubiom, Bk. I, Chap. 24, No. 19; FrIEDBERg, RECHT DER EHESCHLIESSUNG, 3 44; RICHTER, LeHRBUCH DES KATHOLISCHEN UND EVANGELISCHEN KRCHENRECHTS, II26, xI94; 2 v. SCHERER, HANDBUCH DES KIRCHENRECHTS, I63-64; WAITER, LEHRBUCH DES KTRCHENRECHTS, 572-73.

11 I EsMreIN, supra, I69-70.

12 Berardus would follow the Roman law on account of the weakness of the sex. 3 Berardos, Comarentaria in Jus Ecclesiasticun Untversuar, I56.

13 Hostiensis, Sunma AUREa, Lib. III, de Spons. et Matrimonns, Col. I236, No. 7 .

1s I Esmein, supra, I7r.

15 Sext. (Liber Sextus Decretaliuar), I, I9, 9. 
Since the Council of Trent $\left(\mathrm{I}_{5} \mathrm{6}_{3}\right)$ matrimonial consents must be exchanged according to the Canon Law before a priest and at least two witnesses. Otherwise the marriage is invalid. There appears to have been at first considerable dispute among the canonists on the point whether this new requirement affected the rules of the Canon Law relating to marriage by proxy. Some argued that the priest and the witnesses were to identify the parties and ascertain their intention to marry and that this necessitated the presence of both parties. This contention was rejected, it being held that the main object of the provision of the Council of Trent was to give publicity to the marriage, to bring the fact of marriage to the notice of the church. ${ }^{16}$ Thereupon some maintained that the power of attorney must be executed in the presence of a priest and two witnesses, but this view also did not prevail. ${ }^{17}$ The result was that even in those countries in which the Council of Trent was accepted a marriage conforming to the requirements of this Council might be entered into by proxy upon the same conditions, so far as the proxy is concerned, as before. ${ }^{18}$

The decretal above quoted requires that the mandate or power of attorney be special and that it has not been revoked before the celebration of the marriage. ${ }^{19}$ It mentions also the fact that in the absence of an express authorization the proxy shall have no power of substitution. No special form is prescribed for the power of attorney, so that a mere oral authorization would be sufficient. ${ }^{20}$ The agent may be either a man or woman, no distinction being made between the sexes. ${ }^{21}$

The provisions of the Canon Law relating to marriage have

${ }^{16} 5$ Ferraris, Promitta Bibliotheca Canontca, Jurmica, Etc., Matrmiontum, Articulus I, No. 34 .

17 Sanchez, De Sancto Matrmionm Sacramiento Disputationum Toam Tres, Disputatio, Ir, No. 23.

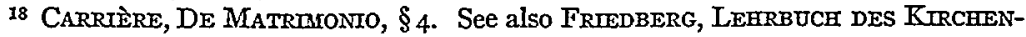
RECHTS, 49o; RICHTER, Ir33; 2 v. SCHERER, supra, r92; v. SCHULTE, LEHRBUCH DES RATHOLISCHEN UND EVANGELISCHEN KTRCHENRECHTS, § 559 ; VAN ESPEN, JUS ECCLESIASticun Universunr, Pt. 2, § I, Tit. I2, No. Io.

The canonists advise parties marrying by proxy to exchange matrimonial consents in person later. SANCHEZ, supra, No. 3I, note.

19 As regards ordinary contracts the continental rule of agency allows the agent to bind the principal notwithstanding a revocation of the agent's authority if the contract was entered into before the agent knew of the revocation.

20 v. SCHERER, sipra, I92.

21 SANCHEZ, silpra, No. I5. 
generally been superseded on the continent to-day by civil marriage acts whose object it is, as their name indicates, to make marriage a purely civil institution. These acts aim to give due publicity to the proposed marriage and to make certain, so far as possible, that the marriage is the voluntary and deliberative act of the parties. Marriage by proxy obviously violates the objects of these acts, for there can be no certainty at the time of the marriage that the power of attorney was not given under circumstances constituting fraud, mistake or duress, or that it was not revoked prior to the celebration of the marriage.

The Code Napoléon does not prohibit marriage by proxy in express terms. Article 75 of the Code requires the officer of the civil status, however, to read to the parties the different documents required by law respecting their civil status and the Code provisions dealing with the mutual rights and duties of husband and wife. This requirement would be purposeless if the parties were not present in person. The framers of the Code ${ }^{22}$ without doubt intended to prohibit marriage by proxy and the provisions of the Code are so understood to-day. ${ }^{23}$ The French writers maintain that in the absence of an express provision in the Code declaring a marriage by proxy void a marriage so celebrated before an officer of the civil status must be deemed valid. ${ }^{24}$ The Court of Bastia has taken the contrary view. ${ }^{25}$

${ }^{22}$ At a meeting of the Council of State the first consul stated without being contradicted by any one "le mariage "z' a plus lien qu' entre persomes présentes." 2 LocRE, Législation Civile, Cosarerciale et CrTanelde, 365.

The ancient law of France allowed marriage by proxy. This was still the law at the time of Pothier. 6 PotaIER, Oevvres, 3 ed., No. 367 .

237 Aubry \& Rau, Cours de Droit Civil Frangais, 5 ed., § 466; 2 Baudry Lacantinerte \& Houques-Fourcade, Tratte Théortque et Pratique de Droit Crvil. Des Personnes, Vol. 2, No. 1597; I Beudant, Cours de Drolt Civil Frangais, No. 222; I Demante, Cours Analytique de Code Civil, 3 ed., 357; 3 Demoloarbe, Cours de Code Napolfon, No. 210; I Duranton, Cours de Droit Français Suivant re Code Civin, No. 287; Fuzier-Heraran, Codes Annotés, Code Civin, Art. 36, Nos. 2 el seq.; Art. 75, No. 5 ; Glasson, DU Consentesarent des Epoux aU Mariage, No. io8; x Huc, Commentatre Thérorique et Pratique du Code Civir, No. 345; 2 Laurent, Principes de Droit Crvit Franchats, No. 427; I Marcade, Explication Theorique et Pratique du Code Napoléon, No. 23x. Contra, Merdin, RÉpertorre, Mariage, Sec. 4, § I, Art. I, QUEst. 4; I Toulliter, Droit CivIL FranGAIS, No. 574.

247 AUBRY \& RAU, supra, § 467; 3 Demoloume, supra, No. 2Io; Glasson, supra, No. IOg; 2 LAURENT, supra, No. 485 .

25 BASTIA, April 2, 1849, D. 49, 2, 80; S. 49, 2, 338 . 
In Belgium the Code Napoleon is law, so that the situation is the same as in France. The Belgian writers agree with the French that a marriage celebrated contrary to the implied prohibition of the Code would be valid. ${ }^{26}$

Under the modern law of Italy marriage by proxy is prohibited except with respect to the King and members of the royal family. ${ }^{27}$

A marriage cannot be celebrated in Germany by proxy since the law of February 6, I875, section 52 of that law requiring the personal presence of both parties. ${ }^{28}$ A reservation is made in favor of the ruling families and the princely House of Hohenzollern. ${ }^{29}$ The present Civil Code made no change in the law. ${ }^{30}$

In Austria the parties may marry by proxy with the consent of the government. ${ }^{31}$ The person with whom the marriage is to take place must be mentioned in the power of attorney. A marriage celebrated without "such special power of attorney" is void. Some of the Austrian writers maintain that the word "such" does not refer to the governmental consent and that the absence of such consent does not render the marriage invalid. ${ }^{32}$ Whether the power of attorney must be in writing is doubtful. ${ }^{33}$

${ }^{26}$ Encyclopéde de Drótt Crvil Belge, I Code Crvit, Ȧrt. 36, No. r, Art. 75, No. 6; 2 Ladrent, supra, No. 427; I THIRY, CoURS DE Droit CrvIL, No. 265.

${ }^{27}$ See Foscauni, I Motivi del Codice Civile del Regno d'Italia, $x 71$; I BoRsart, Combentario de Codice Civile Italiano, § 254; x Catraneo, Il Codice Civile Italtano Annotato, 82.

28 Reichsgesetzblate, I875, 23. So formerly in Prussia, A. L. R. Pt. 2, Tit. r, $\S$ I67; 3 Dernourg, Preussisches Prtvatrecht, 4 ed., 37.

${ }^{29} \S 72$ of above law. The same reservation is contained in Arts. 32, 46, INTroDUCTORY LAW, Civa Code.

${ }^{30}$ A motion made before the second Code Commission to allow marriage by proxy when the bridegroom was in a non-European state was rejected. The need of such an exception did not appear sufficiently great, especially in view of the fact that since the law of May 4, I870, Germans may marry abroad before a diplomatic or consular officer. .5 Protokolle, 5I et seq.; 2 ENDEMANN, LeHRBUCH DES BÜ̈RgerLICHEN RECHTS, 8 and 9 ed., Pt. 2, 83; 4 Plancx, Bürgeruiches Gesetzbuch, 3 ed., 4; 4 Staudinger, KOMARENTAR ZUM BÜRGERICHEN GESETZBUCHE, 7 and 8 ed., 66.

${ }^{31}$ Article 76 , Civil Code. The consent will be given only if sufficient reasons appear. I NIPPEL, ERLÄUTERUNG DES ALLGEMTEINEN BǗRGERIICHEN GESETZBUCHS DER OESTERREICHISCHEN MONARCHEN, 336.

s I Dolliner, Handbuch des in Oesterreich geltenden Eherechts, 308,

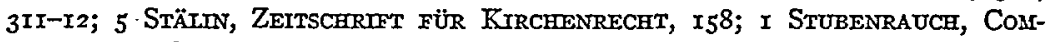
LENTAR ZUN OESTERREICHISCHEN ALLGEMEINEN BÜRGERLICHEN GESETZBUChE, 7 ed., x78. Contra, v. KiRCHSTETter, CoMRTENTAR zUM OESTERREICHISCHEN ALIGEIIEINEN BÜRGERITCHEN GESETZBUCHE, 5 ed., 88.

33 I STUBENRADCH, silpra, 77 . 
Belgium, France, and Italy have authorized marriage by proxy again during the present war. The Belgian law of May 30, I9I6, provides that "during the duration of the war either or both of the parties may appear before the officer of the civil status either in person or by a special and authentic power of attorney." 34 According to Masson, ${ }^{35}$ the law was passed for the benefit of Belgian soldiers residing abroad. The wording of the law gives it a general application.

The French law of April 4, I9I $5,{ }^{36}$ authorized soldiers and sailors with the colors to marry for grave reasons by proxy with the permission of the minister of justice and of the minister of war or the minister of the navy. A circular of the minister of justice of April 8, I9r5, defines more fully the object of the law and the particular steps to be followed. ${ }^{37}$

Soldiers and sailors, employees of the Army and Navy, and persons in the service of the Army and Navy, were authorized in Italy to marry by proxy by a decree of June 24, I9I $5 .^{38}$

34 Masson, LA LEGISLATION DE GUERRE, London, I9I7, I46.

${ }^{25}$ Ibid., I45.

36 Dovergter, La Legrstation Coarplìte des Lois, Etc., I9I5, II3.

The law of August I9, r9I5, has extended the benefit of the law of April 4 to French prisoners of war in Germany. CuUNET, IgI6, 864.

${ }^{37}$ DovERGIER, supra, I9I5, II9, I20.

As grave reasons the following are specified: (I) the existence of illegitimate children; (2) pregnancy; (3) imminent death of either party; (4) promise to marry before mobilization and service in a place dangerous to life.

The proxy must be at least twenty-one years of age and be of the male sex. He must not be a relative within the prohibited degrees of relationship, nor have been convicted of crime.

The power of attorney must be executed in accordance with the law of June 8, I893, relating to acts of persons in the army.

For a criticism of the above provisions see Albert Wahl, "Mariage par Procturation," Revue TrTarestrielle de Droit Civil, IgI5, 5.

${ }^{33} 67$ LA LEGGE (Supplemento Legislativo), Col. 5 II; CLONET, I9I7, II72.

The power of attorney must be special and under penalty of nullity must indicate (I) the first and last name of the person giving the proxy; (2) the age and the place of birth of himself and of the person with whom he contemplates matrimony; (3) if he is a soldier, his rank and the regiment to which he belongs. The power of attorney must be executed in the presence of two witnesses, in conformity with article 2 of the decree of May 23, I9I5. The marriage is valid notwithstanding a defect in the power of attorney at the expiration of six months after the husband has left the military service. 67 LA LEGGE (Supplemento Legislativo), Col. 51r; CIUNET, I9I7, II72.

An agreement was entered into between the French and Italian governments according to which Italian soldiers may get married by proxy in France under the conditions prescribed by the Italian decree of June 24 , I9I5, and by way of reciprocity 
As for England, marriage by proxy is incompatible with the modern marriage acts. ${ }^{39}$ The marriage act of 1898 prescribes that the parties must say in the presence of the registrar or authorized person and of the witnesses, "I call upon these persons here present to witness that $I, A B$, do take thee, $C D$, to be my lawful wedded wife [or husband]," or in lieu thereof the following words: " $I, A B$, do take thee, $\mathrm{CD}$, to be my wedded wife [or husband]." These provisions evidently contemplate the personal presence of the parties and thus preclude the possibility of marrying by proxy.

With respect to this country the matter is not free from difficulty. In some of the states, in which the common-law marriage is no longer recognized, the statutes manifestly require the personal presence of the parties. In other states the statutes are not so clear. In the great majority of states the common-law marriage is still valid, notwithstanding modern statutes relating to the solemnization of marriage. ${ }^{40}$ Is not marriage by proxy valid in these states? The answer will depend in the first place upon the question whether marriage by proxy was recognized by the English law at the time our colonies were settled. On this point there can be little doubt. We need not inquire here whether the general Canon Law had force in England proprio vigore before the time of the Reformation or whether it required acceptance by the King's Ecclesiastical

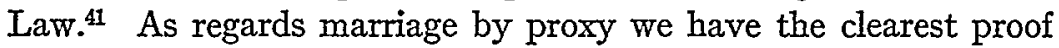
that the Canon Law was so accepted in England, for we find in Lyndwood's Provinciale, written in I43O, which contains the accepted constitutions of the Church of England the following: ${ }^{22}$

"Contractibius matrimonialibus qui non solum possunt fieri utraque parte prasente, sed altera absente ut videlicet contrahatur matrimonium per procuratorem, sicut legitur et notatur de procuratione c. ulti. li. vi et in hoc casu requiritur mandatum speciale ut ibi dicitur: nec potest talis procurator alium substituere, ut ibi dicitur. Absque speciali mandato et si revocetur mandatum talis procuratoris etiam ipso ignorante re integra non tenebit

French soldiers may be married by proxy before the proper Italian officer of the civil status upon compliance with the provisions of the French law of April 4, ror5. See note of Minister of Justice, CLUNET, I9I7, II7 7 .

${ }^{39}$ MarRIaGe ACT, $x 836,6$ \& 7 WILL. IV, c. 85, § 20; MaRRIAGE ACT, I898, 6I \& 62 VICT., c. $58, \S 6$.

40 The states are enumerated in L. R. A. I915E, I9-20; ANN. CAS. $19 \pm 2 D, 598 \mathrm{ff}$.

4i In regard to this question see Maitland, "Canon Law in England," II ENG. HrST.

Rev., 446; Ogle, The Canon Law In Medieval England, London, Igi2.

22 Bretton-Fopyl edition, I505. Fol. CXLVIII. 
contractus ut ibi dicitur. Ratio est quia deficit consensus mandantis et sic videtur quod ubicunque actus gesti per procuratorem debet adesse verus consensus Domini pro substantia actus non est necesse quod revocatio transeat in notitiam procuratoris."

The English law thus adopted the provisions of the Canon Law relative to marriage by proxy. No change was made in this respect by the Reformation. In the reign of Henry VIII the clergy was prohibited from enacting constitutions and ordinances without the King's consent, but the existing Canon Law was continued in force. ${ }^{43}$ A revision of the Canon Law by a commission of thirtytwo members was contemplated by that statute but this revision was never consummated. Mary the Catholic ${ }^{44}$ repealed the above law but it was reënacted under Elizabeth. ${ }^{45}$ The statute of Henry VIII has remained the basis of English ecclesiastical law except in so far as the latter may have been changed by special legislation.

That marriage by proxy was a part of the English law until the eighteenth century would appear from Swinburne's treatise on Espousals in which he says: ${ }^{46}$

"Not only such Persons as be present, but those Persons also which are absent may contract Spousals or Matrimony together. So did Isaac and Rebecca, as it appears in the Sacred Scriptures. Betwixt them that be absent, Spousals or Matrimony may be contracted three manner of ways; that is to say, by Mediation of their Proctors, or of Messengers, or of Letters; provided nevertheless in every of those Cases, that the Parties have some notice or intelligence the one of the other, at hand by Fame or Report; for unto those who be utterly unknozen to us, we cannot yield our Consent, (without the which it is impossible to contract Matrimony or Spousals) no more than it is possible for us to love them, of whom we have never heard."

Swinburne thereupon enters upon a lengthy explanation of the subject, as regards the sufficiency of the power of attorney, the words to be used by the proxy, et cetera.

43 25 HEN. VIII, c. Ig. The statute contains the following provision: "That such canons, constitutions, ordinances, and synodals provincial being already made, which be not contrariant or repugnant to the laws, statutes and customs of this realm, nor to the damage or hurt of the King's prerogative royal, shall now still be used and executed, as they were afore the making of this act, till such time as they be viewed, searched, or otherwise ordered or determined by the said two and thirty persons, or the more part of them, according to the tenor, form and effect of this present act."

41 I \& 2 PH. \& M., c. 8.

45 I ELIZ., c. r.

45 Swinburne, Espousals, 2 ed., 162. 
Did marriage by proxy become a part of the common law of this country? In the absence of decisions on the point no absolutely certain answer can be given to this question. In favor of the validity of marriage by proxy the following may be said. The American colonies are deemed to have brought with them the English law of marriage, so far as it was adapted to their environment. They accepted the then prevailing view that a marriage de praesenti without a religious ceremony constituted a perfect marriage, although the English House of Lords has since declared in the famous case of Regina v. Millis ${ }^{47}$ that this has never been the English law. That such consent might be expressed by an agent was admitted by the Roman law, by the Canon Law, and, according to Swinburne, by the English law as late as the eighteenth century. If marriage by proxy did not become law in this country it must have been because it did not suit our conditions. A comparison of the conditions in England and in the American colonies would lead to the conclusion, however, that during our colonial days there existed stronger reasons for the recognition of marriage by proxy in this country than ever existed in England. Many a colonist must have left his sweetheart behind when he first ventured over seas. Others, without being engaged, must have desired, after becoming established in this country, to marry someone whom they had known in their native land. A trip to the old country for that purpose was long and costly. Unless marriage could be celebrated abroad by proxy the woman would be compelled to go to the man in a strange land and cross the seas unmarried. Marriage by proxy would enable the woman to become the man's wife before leaving her home.

Marriages by proxy have doubtless taken place in this country, but no record thereof can be found in the decisions of the courts. ${ }^{48}$ That there are serious objections to marriage by proxy is apparent. The uncertainty in regard to the legal existence of such a

${ }^{47}$ Io C.. \& F., 534 (I844). That the decision of the House of Lords is historically unsound, see 2 Pollock AND MaItland, supra, 367 et seq.; Bishop, Marriage AND DrVorce, 5 ed., § 276 et seq.; FrIEDBERg, LeHRBUCH DES KRRCHENRECHTS, 309 et seq.; HOWARD, supra, 316 .

Marriage based upon mere present consent came historically to an end in England through Lord Hardwick's Act of x753, 26 GEo. II, c. 33. HaAnitck, THE Marriage LAW OF ENGLAND, 2 ed., I3.

\$8 According to a newspaper report a man in Chicago married recently a woman in Egypt by proxy. 
marriage arising from the fact that the power of attorney is revocable and may have been revoked without knowledge of the other party or the proxy prior to the celebration of the marriage would suggest of itself the expediency of probibiting such a marriage. In view of the fact, however, that marriage by proxy was permissible in England until the eighteenth century and has been recognized in all countries so long as marriage rested upon mere consent, it must be regarded as valid in those states in which the common-law marriage still exists. Should this view be taken by the courts it would follow logically that marriage might be contracted in such a state by proxy; although neither of the parties was present when the consents were exchanged by the proxies.

\section{II}

Turning from the internal law of marriage to marriage by proxy in its intermational aspects, it is apparent that the question relates to the formalities or to the mode in which the marriage must be celebrated. According to the generally accepted view a marriage is valid as regards the mode of celebration if it conforms to the law of the place of celebration..$^{49}$ In nearly all of the countries, including the United States, the rule lex loci celebrationis has a mandatory character, so that a marriage not celebrated in accordance with its provisions is void. ${ }^{50}$ In Italy the marriage is valid if it satisfies as regards form either the law of the place of celebration or the national law of the parties. ${ }^{51}$ Germany recognizes the same principle except that marriages celebrated in Germany must con-

40 Belgium: Brussels, May 29, 1852, Pas. 52, 2, 237. England: Kent v. Burgess, II Sim. 36I (1840); Butler v. Freeman, Ambl. 303 (1756); DiCEy, Conftict of Laws, 2 ed., rule I72; Westrake, Prrvate Internationat, Law, 5 ed., 6o. France: App. Paris, Dec. I8, I837, S. 38, 2, 113; Trib. Civ. Seine, July 27, I897, Clunet, I897, ro29. Uitited States: See note 57 L. R. A., I55-59; StoRy, Conflict of Laws, 8 ed., 216; I Wharton, CONFLict OF LAWs, 3 ed., 366 et seg.

The rule is applied in England and in this country although there has been an evasion of the local law. Compton v. Bearcroft, cited in Middleton v. Janverin, 2 Hagg. C. R. 444, note; Simonin v. Mallac, Sw. \& Tr. 67 (I860). See also Medway v. Needham, I6 Mass. I57 (I8I9); Sturgis v. Sturgis, 51 Ore. Io, 93 Pac. 696 (Ig08); State v. Hand, 87 Neb. 189, r26 N. W. 1002 (rgro); Leefield v. Leefield, 85 Ore. 287, x66 Pac. 953 (1917). Conira, Cunningham v. Cunningham, 206 N. Y. 34I, 99 N. E. 845 (Igx).

so Buzzati, L'Autorità delle Leggr Strantere Relattve Altir Forara degli Atrt Crvitr, 187 et seq.

51 Article 9, Preliminary Dispositions, Crvic Code. 
form in respect of the mode of celebration to the German law of marriage..$^{2}$

From the standpoint of the conflict of laws of the United States the law of the place of celebration will decide, therefore, whether a marriage by proxy is valid. If the lex loci celebrationis allows this mode of celebration it will determine not only all the special questions relating to the power of attorney but also the formalities applicable to marriage in general. This law would decide, for example, whether the power of attorney must be in writing, whether the government consent to such marriage is necessary, and the effect of a failure to obtain such consent. It will control the question whether a mere consent to take each other from the present moment as husband and wife is sufficient to constitute the parties husband and wife, or whether they must be joined in marriage by some official before witnesses and after the publication of banns, etc.

Marriage by proxy is possible under certain conditions in Austria, Belgium, France, and Italy, but it is evident that the legislation relating to marriage by proxy operates only as a waiver of the requirement of personal presence. In all other respects the local provisions relating to the celebration of marriage must be observed. These provisions are far more stringent than those prescribed by the statutes governing the marriage ceremony in this country. The ceremony itself can be performed only by an officer of the civil status, and one of the parties must be domiciled in the place where the marriage is to be celebrated or have lived there for a specified period of time. ${ }^{53}$ The parties must also submit various certificates relating to birth, parental consent, publication of banns, etc., before the marriage can be performed. ${ }^{54}$ For an American it is very difficult, if not impossible, to satisfy these requirements. We have no registers of the civil status in this country; hence no official birth certificates as required by the foreign law can be obtained. Where no birth certificates can be presented the foreign law, it is true, provides a method for proving the time of birth, but such

52 Article $x_{3}$, Introductory Law, Crvil Code; 5 Planck, Bürgerutches GesetzBUCH, 3 ed., 50 .

${ }_{53}$ Belgium, Crval Code, Art. 74; France, Art. 4 of Law of June 21, 1907, repealing Art. 74, Crvil CODE, Duvergrer, 1907, 287; Italy, Art. 93, Crvil Code.

54 Belgium, CrvIr CoDe, Arts. 63 et seq., and Law of December 26, I89r. France, Civil Code, Arts. 63 et seq., and Law of June 2I, Ig07; DuvergIer, I907, 287; Italy, Crvir Code, Art. 79. 
method is frequently of no avail to Americans. For example, Article 70 of the French Civil Code authorizes an acte de notoriété as a substitute for a birth certificate, but this involves a proceeding before a French court in which the facts relating to birth and parentage must be proved by seven witnesses. ${ }^{55}$ In Italy the parties must be competent to marry each other not only under the national law but also according to the Italian law. ${ }^{56}$ The capacity to marry according to the foreign law must be proved by an official certificate. As there is no American official who is authorized by law to execute such a certificate ${ }^{57}$ an American can

${ }_{55}$ The practical impossibility of satisfying these requirements has led in France to an arrangement between the Department of Justice and the American Embassy under which courts will accept a certificate based upon affidavits by an American attorney whose competency is certified by the American Embassy, setting forth the circumstances of birth. See Kelix, The Frenci Law of Marriage, Marriage Contracts AND DIVORCE, 2 ed., 63.

${ }_{56}$ Article I02, Civil Code; App. Ancona, March I2, I884, Foro Italiano, I884, I, 574 .

Article Io2 of the Civil Code reads as follows: "A foreigner's capacity to contract matrimony is governed by the law of the country to which he belongs.

"The foreigner is also subject to the impediments mentioned in Sec. 2, Chap. I, of the present title (Arts. 55 et seq.)."

Among the text-writers there is the greatest dispute concerning the meaning of Article I02. Most of them maintain that the foreigner must comply with the law of his own country and that of Italy. Emilio Bianchi, "Sindi di Diritto Internazionale Privato," ro Archivo Giurmico, 433; 9 De Filippis, Corso Completo di DiritTo Civtre Italiano Comparato, i85-86; x Lomonaco, Istituzioni di Diritto Civile Italiano, 3i6; 7 Pacifici-Mazzont, Istituziont di Diritto Civile Italiano, 3 ed., 83; I Rrcct, Corso di Diritro Crvile, 2 ed., No. 260. But see 5 Bianchr, Corso di Codice Crvile Italiano, 828; I Borsari, CoMrrentario del Codice Crvile Italiano, 382; Esperson, Il Principio di Nazionalità Applicato alle Relazioni Crvili INTERNAZIONALI, 77-78.

According to some writers there is no general test,'but each provision must be examined with a view of ascertaining whether it affects the public policy of Italy or only the private interests of the contracting parties. 2 FIORI, DIRITro INTERNAzIoNale Privato, 3 ed., Nos. 533-34; 2 Gardr, Connrentario dr Codice Crvire, 597.

57 A marriage by an American was annulled in Italy a few years ago on the ground that the American consular agent who had executed such a certificate was not authorized by American law to do so. TrIB. Crv. DE RoMr, June Ig, IgII, Revore DE DroIT International PrIVE, IgI2, 493.

Continental countries regard the parental consent as relating to capacity and not to the formalities of marriage. App. Besançon, January 4, I888, D. 89, 2, 69; App. Florence, August 7, I907, LA LEGGE, I907, 2230; A. G. Celle, January I5, 1870, 24 SEUfFerT's ARCurv, $x$. The consent of parents was formerly regarded in France as relating to the formalities of the marriage. See decision of Parliament of Paris of June 26, 1634, given by I Bounier, Observations sur la Coutunie DU DUChe DE Bourgogne, Chap. 28, 774 . 
marry in Italy only if his capacity has been established in an Italian court. .8 $^{2}$

An American, whether he be a soldier or a civilian, who can meet the above requirements will generally be able to be married in person, so that the foreign legislation on the subject of marriage by proxy is not likely to have great practical importance so far as the United States are concerned.

It is possible, of course, that an American soldier, while he was a prisoner in Germany or Austria, may have desired to marry by proxy a young lady to whom he had become engaged in Belgium, France, or Italy. Such a marriage could not take place in Germany because the German law does not recognize marriage by proxy. If the American were a prisoner in Austria the marriage could be celebrated there only with the permission of the government, and it is most improbable that such a consent could be obtained. Could the marriage be performed at the place of the residence of the fiancée in Belgium, France, or Italy? As the Belgian law of May zo, I9I6, appears to have a general application it would seem as if such a marriage could be celebrated in Belgium. In regard to France and Italy there is doubt. The legislation of these countries applies to persons connected with the Army or Navy, and the question is whether it refers exclusively to the national Army and Navy. In the opinion of Professor Wahl ${ }^{59}$ the French legislation applies also to the Army and Navy of the Allies. If this view is correct the

ss Article 75, Civir Code; 5 Branchi, supra, 833; I Loxronaco, Diritio Civile ITALIANO, 3 I9.

Such a proceeding may be instituted upon a declaration from an American consul that the American authorities do not execute such certificates of capacity. BUzzATr, Le. Droit Internationax Prive D'après les Conventions de la Haye I, Le MARIAGE, 279.

A certificate of capacity according to the national law was formerly required in France by a circular of the Minister of Justice of March I4, I83I (see S. 36, 2, 342) but this requirement is no longer in force. According to a note of the Minister of Justice of August I, IgII, the French officer of the civil status can no longer require of foreigners proof of their capacity to marry according to their national law. SuRville \& ARthuYs, Droit InTERnationaI PrIVk, 6 ed., 373. Under the former requirement it had become the settled practice in France to accept as a substitute for such certificate the opinion of an American attorney whose competency was certified by the American Embassy, that according to the law of the state to which the party belonged parental consent and the publication of banns were not required. KerIy, supra, $57-63$.

59 Wahl, "Mariage par Procuration," Revoe Trmestruelle de Droit CiviL, I9I5, I5. 
American prisoner in Germany could marry his fiancée in France, provided the French legislation is applicable to American soldiers and sailors who are prisoners in foreign countries. ${ }^{60}$

Marriage by proxy, so far as American soldiers are concerned, would have a more practical bearing as regards marriages celebrated in this country. Many American soldiers must have been ordered abroad on such short notice that they were unable to get married before leaving. Suppose that one of these soldiers, feeling that the war might continue several years, should have asked a friend to act as his proxy in this country and that the marriage consents had been exchanged in his behalf with his fiancee in the state in which she lived. If the common-law marriage still existed in that state such marriage would probably be valid, as has been shown above. If the common-law marriage is not authorized in the state of her residence she might go to a neighboring state where it still exists and exchange marriage consents there with her fiancés proxy. Such a marriage, if valid where celebrated, would be recognized by the other states of this country under the ordinary rules governing the conflict of laws. Even the courts of the home state whose law has been evaded would probably recognize the validity of the marriage. American courts have gone to the very extreme in sustaining marriages on grounds of policy, notwithstanding an evasion of the domestic law. As regards legal prohibitions to marry there is a conflict of view on the question, but there appear to be no modern cases in England or the United States which have refused to recognize, on the ground that there has been an evasion of the domestic law, a marriage validly celebrated in accordance with the law of the state where the marriage took place, where the difference in the law concerned merely matters of form. Inasmuch as the question whether a marriage may be entered into by proxy relates clearly to the formalities, a marriage so celebrated in conformity with the local law will be recognized, notwithstanding any evasion of the law of the state in which the parties were domiciled. ${ }^{61}$ A logical

60 The provisions of the law of April 4, I9I 5 , were extended, with respect to French prisoners in Germany, by the Law of August I9, I9I5. CiUNET, I9I6, 864.

61 Upon the reasoning of the court in Freeman's Appeal, 68 Conn. 533, 37 Atl. 420 (1897), it might be argued that inasmuch as marriage by proxy is prohibited in the state in which the power of attorney was given the power of attorney itself is void, so that no marriage can be entered into anywhere by virtue of that power of attorney. The conclusion of the court in the above case as regards the validity of the power of 
application of the principle would enable the parties to get married in a state authorizing marriage by proxy without going there themselves, both parties being represented by proxies. ${ }^{62}$

Ernest G. Lorenzen.

New Haven, CoNn.

attorney is, however, obviously erroneous, and there is no likelihood that any court would follow it with respect to marriage by proxy.

${ }^{62}$ As this article was going through the press, the Judge Advocate General rendered an opinion in which he held that soldiers abroad might marry their sweethearts in the United States through interchanging a marriage contract by mail, provided that such marriage does not contravene state statutes, and that this method might properly be facilitated by the military authorities in France. 